\title{
Pathogens in preterm prelabour rupture of membranes and erythromycin for antibiotic prophylaxis: a retrospective analysis
}

\author{
YY Li, CW Kong *, William WK To
}

\section{A B S T R A C T}

Introduction: Many authoritative guidelines recommend prescribing erythromycin as antibiotic prophylaxis in patients with preterm prelabour rupture of membranes (PPROM). This study evaluated the spectrum of pathogens in PPROM and assessed the effectiveness of erythromycin prophylaxis.

Methods: This retrospective study enrolled pregnant patients who were diagnosed with PPROM and who delivered at $\geq 24$ weeks of gestation in an obstetric unit from 2013 to 2017. Pathogens isolated from maternal, placental, and neonatal specimens were analysed; their sensitivity profiles to various antibiotics were recorded. Neonatal outcomes were also evaluated.

Results: The overall incidence of PPROM was $2.63 \%$. Gram-positive bacteria were cultured in $18.4 \%$ of PPROM patients (most frequent: Group B Streptococcus [GBS; 14.6\%]); Gram-negative bacteria were cultured in $12.8 \%$ of PPROM patients (most frequent:Escherichia coli [8.0\%]). Both Gram-positive and Gram-negative bacteria were significantly associated with early-onset neonatal sepsis $(\mathrm{P}=0.036$
This article was published on 12 Aug 2019 at www.hkmj.org. onset neonatal sepsis $(\mathrm{P}=0.004)$, whereas $\mathrm{GBS}$ was not $(\mathrm{P}=0.39)$. Gram-positive bacteria had high rates of resistance to common antibiotics: $42.2 \%$ of GBS and $50.0 \%$ of Enterococcus and other Streptococcus bacteria were resistant to erythromycin. Escherichia coli had high rates of resistance to ampicillin (70.3\%) and gentamicin (33.3\%); rates of resistance to co-amoxiclav (3.6\%) and intravenous cefuroxime (14.0\%) were low.

Conclusion: Gram-positive and Gram-negative bacteria were found in $29.1 \%$ of PPROM patients. Administration of erythromycin alone was insufficient to control these bacteria in $67.7 \%$ of patients with positive cultures.

Hong Kong Med J 2019;25:287-94

https://doi.org/10.12809/hkmj197991

YY Li, MB, ChB

CW Kong *, MB, ChB, MSC

WWK To, MD

Department of Obstetrics and Gynaecology, United Christian Hospital, Kwun Tong, Hong Kong

* Corresponding author: melizakong@gmail.com

New knowledge added by this study

- Gram-positive and Gram-negative bacteria were found in $29.1 \%$ of patients with preterm prelabour rupture of membranes (PPROM), and the presences of these bacteria were significantly associated with the development of early-onset neonatal sepsis.

- Erythromycin alone is insufficient to control the growth of Gram-positive and Gram-negative bacteria in patients with PPROM. In particular, Escherichia coli and Group B Streptococcus isolates showed high rates of resistance to erythromycin.

Implications for clinical practice or policy

- Based on the increase in Gram-negative bacteria and the association of these bacteria with early-onset neonatal sepsis, intravenous cefuroxime (a second-generation cephalosporin) is proposed for use as antibiotic prophylaxis, in combination with erythromycin, in patients with PPROM.

\section{Introduction}

Preterm prelabour rupture of membranes (PPROM) occurs in $2.0 \%$ to $3.5 \%$ of pregnancies and contributes to $30 \%$ to $40 \%$ of all preterm births. ${ }^{1}$ Importantly, PPROM is directly associated with preterm labour, prematurity, chorioamnionitis, maternal and neonatal infections, and adverse maternal and neonatal outcomes. ${ }^{2}$ Patients with
PPROM reportedly have a higher rate of abnormal microbial colonisation of the genital tracts than patients without PPROM; the prevalence of positive amniotic-fluid cultures in PPROM patients is approximately $32 \%$ to $35 \% .^{1}$ Administration of antibiotics in PPROM patients has been shown to significantly reduce clinical chorioamnionitis; delay the onset of delivery; decrease neonatal infection; 


\section{未足月胎膜早破的病原體和以紅徽素作抗生素 預防療法：回顧性分析 \\ 李恩瑜、江采華、杜榮基}

引言：很多權威指引都推薦使用紅徽素作為未足月胎膜早破 (PPROM) 病人的抗生素預防療法。本研究評估PPROM的病原體系 列和探討紅徽素的預防功效。

方法：這項回顧性研究納入2013年至2017年在一個產科部門出現 PPROM並且在懷孕 24 週後生產的病人。我們分析從母體、胎盤及初 生嬰兒樣本中培植出來的病原體, 並且記錄它們對多種抗生素的敏感 性。初生嬰兒的產後狀況也一併分析。

結果：PPROM的總體發生率是 $2.63 \%$ 。有 $18.4 \%$ P PROM病人培 植出革蘭氏陽性菌（當中最常見的是 B型鏈球菌，佔 $14.6 \%$ ); $12.8 \%$ PPROM病人培植出革蘭氏陰性菌（當中最常見的是大腸桿菌， 佔 $8.0 \%$ ）。革蘭氏陽性菌和陰性菌都與早發性新生兒敗血症有重要關 係 $(\mathrm{P}=0.036, \mathrm{P}=0.001)$ 。當每種病原體獨立分析, 我們發現大腸 桿菌與早發性新生兒敗血症有重要關係（ $\mathrm{P}=0.004 ）$, 但 $\mathrm{B}$ 型鏈球菌 則沒有（ $\mathrm{P}=0.39 ） 。$ 革蘭氏陽性菌對常用的抗生素呈抗藥性 : $42.2 \%$ 的B型鏈球菌、 $50 \%$ 的腸球菌及其他鏈球菌都對紅徽素呈抗藥性。 大腸桿菌對氨芳青徽素及慶大霰素呈很高抗藥性（分別佔 $70.3 \%$ 及 $33.3 \%$ ），但對阿莫西林克拉維酸鉀及靜脈注射頭狍呋辛則呈低抗藥 性（分別佔 $3.6 \%$ 及 $14.0 \%$ )

結論：我們在 $29.1 \%$ PPROM病人中發現有革蘭氏陽性菌和陰性菌。紅 徽素沒法壓制當中 $67.7 \%$ 培植出的細菌。 and reduce the use of surfactant, oxygen therapy, and abnormal neonatal cerebral ultrasound prior to discharge from hospital. ${ }^{3}$

A randomised controlled trial published in 1997 showed that the use of erythromycin and ampicillin as antibiotic prophylaxis in PPROM patients could significantly reduce neonatal morbidity. ${ }^{4}$ In 2001, the landmark randomised controlled trial ORACLE 1 showed that the use of erythromycin could significantly prolong pregnancy in PPROM patients and could improve neonatal outcomes. ${ }^{1}$ Based on the above two trials, many authoritative guidelines recommend prescribing erythromycin with or without ampicillin for PPROM patients, including guidelines from the Royal College of Obstetricians and Gynecologists, ${ }^{5}$ the American College of Obstetricians and Gynecologists, ${ }^{6}$ the Society of Obstetricians and Gynaecologists of Canada, ${ }^{7}$ and the Royal Australian and New Zealand College of Obstetricians and Gynaecologists. ${ }^{8}$

However, more recent studies have found that colonisation by Gram-negative bacteria, especially Escherichia coli, has been increasing in PPROM patients, such that these bacteria constitute a significant proportion of all pathogens involved in cases of PPROM and early-onset neonatal sepsis., ${ }^{9,10}$ Because the above two trials were conducted nearly 20 years ago, the objective of this study was to re- evaluate the pathogens involved in PPROM and characterise their respective sensitivity profiles to guide the appropriate choice of antibiotics used for optimal control, and to assess whether erythromycin remains an effective antibiotic to control these pathogens in PPROM patients.

\section{Methods}

This was a retrospective analysis of a cohort of all pregnant patients who were diagnosed with PPROM and who delivered at $\geq 24$ weeks of gestation in United Christian Hospital from 1 January 2013 to 31 December 2017. These patients were identified and retrieved from the labour ward registry. Diagnoses of PPROM were made based on clinical history and speculum examination to determine the presence of liquid leaking from the cervical os; ultrasound was performed when necessary to aid the diagnosis of PPROM. In accordance with our department protocol, all patients who were diagnosed with PPROM underwent microbiological investigation, including high vaginal swab and mid-stream urine for bacterial culture, and low vaginal swab and rectal swab for Group B Streptococcus (GBS) culture. Maternal blood culture was performed if maternal fever or signs of acute chorioamnionitis were observed. Microbiological investigation was repeated when clinically indicated. All patients who were diagnosed with PPROM were administered oral erythromycin $250 \mathrm{mg}$, 4 times per day for 10 days, unless labour was established; patients at $<35$ weeks of gestation were administered intramuscular dexamethasone to enhance fetal lung maturity, in accordance with the NICE guideline adopted by the Royal College of Obstetricians and Gynaecologists. ${ }^{5}$ Conservative management was adopted for patients at $<34$ weeks of gestation, unless there was evidence of acute chorioamnionitis or preterm labour was established. Possible induction of labour was discussed with patients at $\geq 34$ weeks of gestation. Caesarean section was performed in accordance with obstetric indications. Erythromycin was changed to another appropriate antibiotic if culture results demonstrated the presence of erythromycinresistant bacteria. If a patient had spontaneous or induced labour, intravenous benzyl penicillin was administered to control GBS until the baby was delivered. For all PPROM patients, placental swabs were sent for bacterial culture and the placentae were sent for histology examination after delivery. All neonates were assessed by paediatricians after birth and appropriate neonatal cultures were taken as indicated. Regardless of the presence of positive bacterial cultures, neonates were diagnosed with early-onset neonatal sepsis if they had signs of systemic infection within 72 hours after birth; these signs included unstable body temperature, lethargy or irritability, feeding intolerance, respiratory 
distress, tachycardia or hypotension, metabolic changes (eg, glucose level and acidosis), neutropenia, or increased acute-phase reactants (eg, C-reactive protein).

The demographic and clinical data of the pregnant patients and their neonates were retrieved from a comprehensive obstetric database and the Clinical Management System of the Hospital Authority. The SPSS (Windows version 20.0; IBM Corp, Armonk [NY], United States) was used for data entry and analysis. Continuous variables were analysed by $t$ test, whereas discrete variables were analysed by the Chi squared test or Fisher's exact test. A P value of $<0.05$ was considered to be statistically significant. The STROBE (Strengthening the Reporting of Observational Studies in Epidemiology) guidelines were followed in the preparation of this article. $^{11}$

\section{Results}

In total, there were 21047 pregnancies with 21375 babies delivered during the study period, including 324 pairs of twins and two sets of triplets. The incidence of PPROM was 2.63\% (553/21047), including 39 pairs of twins. The demographic data and pregnancy outcomes of patients with and without PPROM are shown in Table 1. Advanced maternal age, primiparity, and multiple pregnancies were more common among patients in the PPROM group than among patients in the non-PPROM group. Patients with PPROM delivered earlier (34.1 vs 38.8 weeks; $\mathrm{P}<0.0001)$ and had lower birthweight babies (2260 g vs 3142 g; $\mathrm{P}<0.001$ ) than patients without PPROM. The incidence of neonatal death was higher in the PPROM group than in the nonPPROM group $(1.4 \%$ vs $0.1 \% ; \mathrm{P}<0.001)$, whereas the incidence of stillbirth did not significantly differ between the two groups $(0.3 \%$ vs $0.3 \%$; $\mathrm{P}=0.73)$.
The outcomes of patients with PPROM and the types of bacteria cultured from maternal, placental, and neonatal specimens are shown in Table 2. Grampositive bacteria were found in $18.4 \%$ of PPROM patients, among which GBS was the most common (14.6\%); Gram-negative bacteria were found in $12.8 \%$ of PPROM patients, among which E coli (8.0\%) was the most common. In addition, anaerobes were found in $1.8 \%$ of PPROM patients. Although 19.2\% of placental histology specimens showed evidence of chorioamnionitis or funisitis, only $4.7 \%$ of PPROM patients were clinically diagnosed with acute chorioamnionitis. However, early-onset neonatal sepsis was diagnosed in $10.8 \%$ of newborns.

Preterm prelabour rupture of membranes occurred earlier in gestation in patients with earlyonset neonatal sepsis than in those without neonatal sepsis (31.1 vs 34.2 weeks; $\mathrm{P}<0.001$ ), and the PPROM to delivery interval was longer in patients with earlyonset neonatal sepsis ( 3.7 vs 1.5 days; $\mathrm{P}<0.001$ ). The presences of Gram-positive bacteria and Gramnegative bacteria were significantly associated with the development of early-onset neonatal sepsis ( $P=0.036$ and $P=0.001$, respectively), whereas the presence of anaerobes was not $(\mathrm{P}=0.08)$. In addition, the presence of $E$ coli was significantly associated with the development of early-onset neonatal sepsis $(\mathrm{P}=0.004)$, whereas the presence of GBS was not $(\mathrm{P}=0.39)$ [Table 3].

The rates of resistance of Gram-positive bacteria and Gram-negative bacteria to various antibiotics are shown in Tables 4 and 5, respectively. All GBS isolates were sensitive to penicillin, but $42.2 \%$ of them were resistant to erythromycin; other Streptococcus and Enterococcus isolates also showed resistance to erythromycin (50\% of each group). Escherichia coli isolates demonstrated high rates of resistance to ampicillin (70.3\%) and gentamicin

TABLE I. Demographic data and pregnancy outcomes of patients with and without PPROM*

\begin{tabular}{lccc}
\hline Demographic data & $\begin{array}{c}\text { Patients with PPROM } \\
(\mathbf{n}=\mathbf{5 5 3})\end{array}$ & $\begin{array}{c}\text { Patients without } \\
\text { PPROM (n= 20 494) }\end{array}$ & P value (95\% Cl) \\
\hline Maternal age & $33.0 \pm 5.3$ & $32.1 \pm 5.2$ & $<0.001(0.39-1.26)$ \\
\hline Advanced maternal age ( $\geq 35$ years) & $219(39.6 \%)$ & $6712(32.8 \%)$ & 0.001 \\
\hline Primiparous & $332(60.0 \%)$ & $9958(48.6 \%)$ & $<0.001$ \\
\hline Multiple pregnancy & $39(7.1 \%)$ & $287(1.4 \%)$ & $<0.001$ \\
Caesarean delivery & $142(25.7 \%)$ & $4687(22.9 \%)$ & 0.12 \\
Gestation at delivery (weeks) & $34.1 \pm 2.6$ & $38.8 \pm 1.75$ & $<0.001(-4.83$ to -4.53$)$ \\
Birthweight (g)† & $2260 \pm 547$ & $3142 \pm 481$ & $<0.001(-921.37$ to -842.49$)$ \\
Stillbirth $\dagger$ & $2(0.3 \%)$ & $69(0.3 \%)$ & 0.73 \\
\hline Neonatal death $\dagger$ & $8(1.4 \%)$ & $20(0.1 \%)$ & $<0.001$ \\
\hline
\end{tabular}

Abbreviations: $\mathrm{Cl}$ = confidence interval; PPROM = preterm prelabour rupture of membranes

* Data are shown as mean \pm standard deviation or No. (\%), unless otherwise specified

† There were 592 babies in the group with PPROM and 20783 babies in the group without PPROM 
TABLE 2. Pregnancy outcomes and microbiology investigation results in women with $\operatorname{PPROM}(\mathrm{n}=553)^{*}$

\begin{tabular}{|c|c|}
\hline & Value† \\
\hline \multicolumn{2}{|l|}{ Pregnancy outcomes } \\
\hline Gestation at PPROM (weeks) & $33.5 \pm 2.9$ \\
\hline Gestation at delivery (weeks) & $34.1 \pm 2.6$ \\
\hline PPROM to delivery interval (days) & $1.7 \pm 4.5$ \\
\hline Clinical diagnosis of acute chorioamnionitis & $26(4.7 \%)$ \\
\hline $\begin{array}{l}\text { Chorioamnionitis with and without funisitis from pathological } \\
\text { examination }\end{array}$ & $106(19.2 \%)$ \\
\hline Early-onset neonatal sepsis & $60(10.8 \%)$ \\
\hline \multicolumn{2}{|l|}{ Microbiology investigation results } \\
\hline $\begin{array}{l}\text { Gram-positive bacteria found in maternal, placental, or } \\
\text { neonatal cultures }\end{array}$ & $102(18.4 \%)$ \\
\hline Group B Streptococcus & $81(14.6 \%)$ \\
\hline Other Streptococcus & $9(1.6 \%)$ \\
\hline Enterococcus & $6(1.1 \%)$ \\
\hline Staphylococcus & $6(1.1 \%)$ \\
\hline $\begin{array}{l}\text { Gram-negative bacteria found in maternal, placental, or } \\
\text { neonatal cultures }\end{array}$ & $71(12.8 \%)$ \\
\hline Escherichia coli & $44(8.0 \%)$ \\
\hline Klebsiella & $9(1.6 \%)$ \\
\hline Bacteroides & $5(0.9 \%)$ \\
\hline Proteus & $4(0.7 \%)$ \\
\hline Prevotella & $4(0.7 \%)$ \\
\hline Citrobacter & $2(0.4 \%)$ \\
\hline Enterobacter & $1(0.2 \%)$ \\
\hline Morganella & $1(0.2 \%)$ \\
\hline Aggregatibacter aphrophilus & $1(0.2 \%)$ \\
\hline Anaerobes found in maternal, placental, or neonatal cultures & $10(1.8 \%)$ \\
\hline Peptostreptococcus & $7(1.3 \%)$ \\
\hline Bifidobacterium dentium & $1(0.2 \%)$ \\
\hline Peptoniphilus harei & $1(0.2 \%)$ \\
\hline Clostridium & $1(0.2 \%)$ \\
\hline
\end{tabular}

Abbreviation: PPROM = preterm prelabour rupture of membranes

* Data are shown as mean \pm standard deviation or No. (\%) of patients

+ Fourteen patients had mixed bacterial cultures, of which 12 had mixed Grampositive and Gram-negative bacterial cultures. Positive bacterial culture cases are listed literature. ${ }^{1}$ The identified risk factors for PPROM included advanced maternal age, primiparity, and multiple pregnancies. Our cohort showed that women with PPROM had greater incidences of preterm deliveries, lower birthweight babies, and neonatal death, confirming a relationship between PPROM and major neonatal morbidity and mortality.

\section{Roles of Gram-positive and Gram-negative bacteria in neonatal sepsis}

A Korean study compared the incidences of earlyonset neonatal sepsis in cases of PPROM between two periods (1996-2004 and 2005-2012) and found that the incidences of early-onset neonatal sepsis due to Gram-positive bacteria were similar (1.5\% vs $1.6 \%$, $\mathrm{P}=1.0$ ) between the two periods, while the incidences of early-onset neonatal sepsis due to Gram-negative bacteria were significantly different $(0.6 \%$ vs $2.7 \%$, $\mathrm{P}=0.04) .{ }^{10}$ In our cohort, the incidence of early-onset neonatal sepsis due to Gram-positive bacteria was $3.1 \%$ (17/553), while the incidence of early-onset neonatal sepsis due to Gram-negative bacteria was $2.9 \%(16 / 553)$. An Israeli study investigated patients with preterm delivery ( $<37$ weeks of gestation) who had maternal fever, chorioamnionitis, or PPROM; the results showed that early-onset neonatal sepsis was caused by $E$ coli in $80 \%$ of patients (12/15), whereas it was not caused by GBS in any patients. ${ }^{9}$ In our cohort, the incidences of early-onset neonatal sepsis caused by GBS and $E$ coli were both $2.0 \%$ $(11 / 553)$. However, the presence of $E$ coli in maternal, placental, or neonatal specimens was significantly associated with the development of early-onset neonatal sepsis $(\mathrm{P}=0.004)$; this relationship was not observed with respect to GBS $(\mathrm{P}=0.39)$. This was likely because of the prophylactic erythromycin that was administered when patients were diagnosed with PPROM and the benzyl penicillin administered when these patients were in labour; these antibiotics were able to partially control GBS, but were generally unable to control $E$ coli. Therefore, it is important to administer an antibiotic that can control both Grampositive and Gram-negative bacteria in PPROM patients.

\section{Insufficient control of Escherichia coli by ampicillin and erythromycin}

There have been very few studies regarding colonisation of female genital tracts by $E$ coli, especially among pregnant patients. In an analysis of 514 patients with female genital tract infections during 2016 and 2017, 17.7\% of the infections were found to be caused by $E$ coli; its rate of resistance to ampicillin was $67 \%(61 / 91) .{ }^{12}$ A large study regarding the resistance of $E$ coli in urinary tract infections ( $\mathrm{n}=42033)$ from 1999 to 2009 found that

its rate of resistance to ampicillin was $58.3 \%{ }^{13}$ Such
The incidence of PPROM was $2.63 \%$ in our coh

which was consistent with prior reports in the

(33.3\%), but low rates of resistance to co-amoxiclav our laboratory did not routinely perform sensitivity testing of $E$ coli to erythromycin because of its presumed resistance to the antibiotic.

\section{Discussion}


TABLE 3. Comparison of PPROM patients with and without early-onset neonatal sepsis*

\begin{tabular}{|c|c|c|c|}
\hline Clinical characteristics and microbiological investigation & $\begin{array}{l}\text { With early-onset } \\
\text { neonatal sepsis } \\
\qquad(n=60)\end{array}$ & $\begin{array}{l}\text { No early-onset } \\
\text { neonatal sepsis } \\
(n=493)\end{array}$ & $\mathrm{P}$ value $(95 \% \mathrm{Cl})$ \\
\hline Gestation at PPROM (weeks) & $31.1 \pm 4.1$ & $34.2 \pm 2.5$ & $<0.001(-3.83$ to -2.37$)$ \\
\hline Gestation at delivery (weeks) & $31.6 \pm 3.9$ & $34.4 \pm 2.3$ & $<0.001(-3.46$ to -2.09$)$ \\
\hline PPROM to delivery interval (days) & $3.7 \pm 7.6$ & $1.5 \pm 3.9$ & $<0.001(1.05-3.44)$ \\
\hline Gram-positive bacteria in maternal, placental, or neonatal cultures $\ddagger$ & $17(28.3 \%)$ & $85(17.2 \%)$ & 0.036 \\
\hline GBS in maternal, placental, or neonatal culturesł & $11(18.3 \%)$ & $70(14.2 \%)$ & 0.39 \\
\hline Gram-negative bacteria in maternal, placental, or neonatal cultures $\ddagger$ & $16(26.7 \%)$ & $55(11.2 \%)$ & 0.001 \\
\hline E coli in maternal, placental, or neonatal cultures $\ddagger$ & $11(18.3 \%)$ & $36(7.3 \%)$ & 0.004 \\
\hline Anaerobes in maternal, placental, or neonatal cultures $\ddagger$ & $3(5.0 \%)$ & $7(1.4 \%)$ & 0.08 \\
\hline
\end{tabular}

Abbreviations: $\mathrm{Cl}=$ confidence interval; $E$ coli = Escherichia coli; GBS = group B Streptococcus; PPROM = preterm prelabour rupture of membranes

* Data are shown as mean \pm standard deviation or No. (\%) of patients, unless otherwise specified

† For twin pregnancies, if either one of the neonates or both had early-onset neonatal sepsis, that pregnancy was considered to have early-onset neonatal sepsis

$\ddagger$ Four patients with mixed bacterial growth had early-onset neonatal sepsis and all cultured bacteria were included for analysis

data were consistent with our findings that $70.3 \%$ of $E$ coli isolates were resistant to ampicillin. With the exception of a meta-analysis in Ethiopia that showed $52.9 \%$ of $E$ coli isolates were resistant to erythromycin, ${ }^{14}$ very few studies in the literature have investigated the extent of $E$ coli resistance to erythromycin. It is generally believed that $E$ coli isolates are intrinsically resistant to low-level macrolide antibiotics due to plasmid-mediated resistance; this includes a high rate of resistance to erythromycin. ${ }^{15}$ Therefore, erythromycin is rarely used to treat $E$ coli infection, and most laboratories, including our centre, do not routinely perform erythromycin sensitivity testing for $E$ coli.

TABLE 4. Proportions of cultured Gram-positive bacteria that were resistant to erythromycin or penicillin

\begin{tabular}{lcc}
\hline Gram-positive bacteria & $\begin{array}{c}\text { Erythromycin } \\
\text { resistance }\end{array}$ & $\begin{array}{c}\text { Penicillin } \\
\text { resistance }\end{array}$ \\
\hline Group B Streptococcus & $19 / 45(42.2 \%)$ & $0 / 77$ \\
Other Streptococcus & $4 / 8(50.0 \%)$ & $0 / 8$ \\
Enterococcus & $2 / 4(50.0 \%)$ & Not available \\
Staphylococcus & $0 / 2$ & Not available \\
\hline
\end{tabular}

However, most international guidelines ${ }^{5-8}$ currently recommend the use of erythromycin, with or without ampicillin, in PPROM patients. Based on the findings in our study, this antibiotic regimen does not provide adequate control of $E$ coli, as it was most frequently identified as the cause of early-onset neonatal sepsis.

\section{Insufficient control of Group B Streptococcus by erythromycin}

Group B Streptococcus was detected in $14.6 \%$ of maternal, placental, and neonatal specimens in our cohort; similarly, in a study published in 2014, Yeung et $\mathrm{al}^{2}$ reported a GBS maternal carrier rate of $12.5 \%$ in PPROM patients. They found that the rate of resistance to erythromycin was $65 \%$ among GBS isolates, and that the incidence of neonatal GBS infection was significantly lower in patients who received penicillin than in those who received erythromycin $(0.0 \%$ vs $36.4 \% ; \mathrm{P}=0.012)$. In addition, Yeung et $\mathrm{al}^{2}$ suggested that, instead of erythromycin, ampicillin or amoxicillin should be administered to PPROM patients who are active GBS carriers or whose GBS status is unknown. Although our cohort demonstrated a lower rate

TABLE 5. Proportions of cultured Gram-negative bacteria that were resistant to various antibiotics

\begin{tabular}{|c|c|c|c|c|c|c|}
\hline \multirow[t]{2}{*}{ Gram-negative bacteria } & \multirow{2}{*}{$\begin{array}{l}\text { Ampicillin } \\
\text { resistance }\end{array}$} & \multirow{2}{*}{$\begin{array}{l}\text { Co-amoxiclav } \\
\text { resistance }\end{array}$} & \multirow{2}{*}{$\begin{array}{l}\text { Gentamicin } \\
\text { resistance }\end{array}$} & \multirow{2}{*}{$\begin{array}{c}\text { Cefuroxime } \\
\text { (intravenous) } \\
\text { resistance }\end{array}$} & \multicolumn{2}{|c|}{ Cefuroxime (oral) } \\
\hline & & & & & Resistance & $\begin{array}{c}\text { Intermediate } \\
\text { sensitivity }\end{array}$ \\
\hline Escherichia coli & $26 / 37(70.3 \%)$ & $1 / 28(3.6 \%)$ & $14 / 42(33.3 \%)$ & 6/43 (14.0\%) & $5 / 44(11.4 \%)$ & $14 / 44$ (31.8\%) \\
\hline Klebsiella & 8/9 (88.9\%) & $0 / 7$ & $0 / 8$ & $0 / 7$ & $0 / 9$ & $2 / 9(22.2 \%)$ \\
\hline Proteus & $4 / 4(100.0 \%)$ & $1 / 3(33.3 \%)$ & $1 / 4(25.0 \%)$ & 1/3 (33.3\%) & NA & NA \\
\hline
\end{tabular}

Abbreviation: $\mathrm{NA}=$ not available 
of resistance (42.2\%) of GBS to erythromycin, we agree that the administration of erythromycin alone is insufficient to control GBS. In addition, our findings demonstrated that approximately half of the other Gram-positive bacterial isolates, including Enterococcus and other Streptococcus bacteria, were resistant to erythromycin; thus, the overall number of Gram-positive bacterial isolates controlled by erythromycin could be as low as $42.4 \%(25 / 59)$.

\section{Potential use of other antibiotics and clinical implications}

Escherichia coli was found to have a low rate of resistance to co-amoxiclav (3.6\%); GBS was also expected to be sensitive to co-amoxiclav because none of the GBS isolates were resistant to penicillin in our cohort. However, the ORACLE 1 trial found that the use of co-amoxiclav in PPROM patients was significantly associated with an increased incidence of neonatal necrotising enterocolitis, compared with the use of other antibiotics $(1.8 \%$ vs $0.7 \%, \mathrm{P}=0.0005){ }^{1}$ Most international guidelines discourage the use of co-amoxiclav because of this finding..$^{5-8} \mathrm{~A}$ Cochrane systematic review in 2013 assessed 22 randomised controlled trials regarding the use of prophylactic antibiotics in PPROM; only three small trials had compared the incidence of neonatal necrotising enterocolitis between placebo and other penicillins that were not co-amoxiclav. ${ }^{3}$ Two trials investigated the use of mezlocillin $(n=47$ and $n=40)$, whereas the other investigated the use of piperacillin $(n=37)$; none found an increased incidence of neonatal necrotising enterocolitis. ${ }^{16-18}$ Mezlocillin is no longer available in the market as it has been replaced by other penicillins with better bacterial coverage such as piperacillin and ticarcillin. Piperacillin is typically reserved for more severe infections that are resistant to cephalosporin; thus, it is seldom prescribed as first-line treatment. Therefore, piperacillin may not be suitable for use as antibiotic prophylaxis in asymptomatic PPROM patients without evidence of acute chorioamnionitis. In our cohort, $E$ coli had a $14.0 \%$ of rate of resistance to intravenous cefuroxime, and Klebsiella showed no resistance; thus, intravenous cefuroxime could be appropriate for controlling both Gram-positive and Gram-negative bacteria. Thus far, there have been no studies regarding the use of cefuroxime in patients with PPROM. A large study regarding antibiotic resistance rates of $E$ coli isolates in urinary tract infections $(\mathrm{n}=42033)$, from 1999 to 2009 , found that the rate of resistance to cefuroxime was $3.7 \%{ }^{13}$ Finally, one third (33.3\%) of $E$ coli isolates were resistant to gentamicin in our cohort. A threshold of $20 \%$ has been suggested as the degree of resistance at which an antibiotic should no longer be used empirically. ${ }^{19}$ Because of the resistance of $E$ coli to gentamicin and its potential side-effects in terms of ototoxicity and nephrotoxicity, gentamicin is not recommended as a routine prophylactic antibiotic in PPROM.

A study in Korea published in 2016 proposed the use of a combination of ceftriaxone, clarithromycin, and metronidazole in PPROM patients, and this new regimen was shown to more frequently eradicate intra-amniotic inflammation or infection, as well as to more frequently prevent secondary intra-amniotic inflammation or infection, compared with an antibiotic regimen which included ampicillin and/or cephalosporin. ${ }^{20}$ In our cohort, only $1.8 \%$ of maternal, placental, or neonatal specimens demonstrated growth of anaerobes, and these were not associated with early-onset neonatal sepsis. Therefore, the use of metronidazole may not be essential in PPROM patients. In the current recommendations from a variety of international guidelines, erythromycin remains the most commonly used macrolide with an established safety profile in perinatal use, relative to other next-generation macrolides, such as clarithromycin. Therefore, we recommend continued usage of erythromycin in PPROM patients, rather than clarithromycin. However, Gram-positive and Gram-negative bacteria were found in a total of $29.1 \%(161 / 553)$ patients with PPROM in our cohort. Based on the presumption that all Gram-negative bacterial isolates were resistant to erythromycin, the use of erythromycin alone as a broad-spectrum antibiotic regimen was insufficient for control of Gram-positive and Gram-negative bacteria in $67.7 \%(109 / 161)$ of these culture-positive patients, or $19.7 \%(109 / 553)$ of all patients with PPROM in our cohort. Therefore, additional antibiotics are needed to achieve better control of GBS and Gramnegative bacteria, particularly $E$ coli. Co-amoxiclav is not recommended because it is associated with an increased risk of neonatal necrotising enterocolitis. Based on our findings, we propose the addition of intravenous cefuroxime. Ceftriaxone, a thirdgeneration cephalosporin, is presumed to be equally effective, or to be more effective than cefuroxime, in controlling Gram-negative bacteria. However, because of the risk of generating drug resistance in other bacteria, such as Enterobacter, ${ }^{21,22}$ thirdgeneration cephalosporins may not be suitable for use in empirical antibiotic prophylaxis in asymptomatic PPROM patients without evidence of acute chorioamnionitis.

Oral cefuroxime is more convenient to prescribe than intravenous cefuroxime in PPROM patients. However, Gram-negative bacteria were more sensitive to intravenous cefuroxime than oral cefuroxime in our cohort: $31.8 \%$ of $E$ coli and $22.2 \%$ of Klebsiella only showed intermediate sensitivity to oral cefuroxime. Therefore, we recommend the administration of a 1-week course of intravenous cefuroxime in PPROM patients, combined with 10 days of oral erythromycin. Furthermore, the efficacy 
of a combined regimen, such as 3 days of intravenous cefuroxime followed by 4 days of oral cefuroxime, together with oral erythromycin, needs additional analysis to determine whether they are comparable in PPROM patients.

\section{Limitations of this study}

There were some limitations in our study. First, our hospital laboratory did not perform sensitivity testing of Gram-negative bacteria (including $E$ coli) to erythromycin, because of its assumed resistance. Second, our hospital laboratory did not perform sensitivity testing of all isolated pathogens; instead, it performed testing of pathogens with significant growth in culture, and such testing was limited to the most commonly used antibiotics. Therefore, the full spectrum of sensitivity of identified pathogens to various possible antibiotics could not be fully established from the available data. Because of our departmental guidelines for prescribing intrapartum benzyl penicillin for patients with preterm labour, the clinical outcomes observed in our cohortparticularly with regard to early-onset neonatal sepsis-could have been influenced by the combined use of erythromycin and intrapartum benzyl penicillin, rather than by the effect of erythromycin alone.

\section{Conclusion}

Use of erythromycin with or without ampicillin was insufficient to control Gram-positive and Gram-negative bacterial growth in patients with PPROM. Based on the increase in Gram-negative bacteria and the association of these bacteria with the development of early-onset neonatal sepsis, intravenous cefuroxime (a second-generation cephalosporin) is proposed for use as antibiotic prophylaxis, in combination with erythromycin. Further studies regarding the use of erythromycin combined with intravenous cefuroxime in PPROM patients are suggested to investigate the efficacies of these antibiotics for preventing early-onset neonatal sepsis, and to explore their side-effects, such as the development of neonatal necrotising enterocolitis.

\section{Author contributions}

All authors had full access to the data, contributed to the study, approved the final version for publication, and take responsibility for its accuracy and integrity.

Concept or design of the study: CW Kong.

Acquisition of data: YY Li.

Analysis or interpretation of data: All authors.

Drafting of the article: $\mathrm{YY} \mathrm{Li}, \mathrm{CW}$ Kong.

Critical revision for important intellectual content: WWK To.

\section{Conflicts of interest}

All authors have disclosed no conflicts of interest.

\section{Funding/support}

This research received no specific grant from any funding agency in the public, commercial, or not-for-profit sectors.

\section{Ethics approval}

Ethics approval for this study was granted by the Kowloon Central/Kowloon East Research Ethics Committee (KC/ KE18-0190/ER-1). As this study was a retrospective review, the need for individual patient consent was waived by the research ethics committee.

\section{References}

1. Kenyon SL, Taylor DJ, Tarnow-Mordi W; ORACLE Collaborative Group. Broad-spectrum antibiotics for preterm, prelabour rupture of fetal membranes: the ORACLE I randomised trial. ORACLE Collaborative Group. Lancet 2001;357:979-88.

2. Yeung SW, Sahota DS, Leung TY. Comparison of the effect of penicillins versus erythromycin in preventing neonatal group B Streptococcus infection in active carriers following preterm prelabor rupture of membranes. Taiwan J Obstet Gynecol 2014;53:210-4.

3. Kenyon S, Boulvain M, Neilson JP. Antibiotics for preterm rupture of membranes. Cochrane Database Syst Rev 2013;(12):CD001058.

4. Mercer BM, Miodovnik M, Thurnau GR, et al. Antibiotic therapy for reduction of infant morbidity after preterm premature rupture of the membranes. A randomized controlled trial. National Institute of Child Health and Human Development Maternal-Fetal Medicine Units Network. JAMA 1997;278:989-95.

5. National Institute for Health and Care Excellence. Preterm labour and birth. NICE guideline (NG25). Available from: https://www.nice.org.uk/guidance/ng25/resources/ preterm-labour-and-birth-pdf-1837333576645. Accessed 2 May 2019.

6. Committee on Practice Bulletins-Obstetrics. ACOG Practice Bulletin No. 188: Prelabor rupture of membranes. Obstet Gynecol 2018;131:e1-14.

7. Yudin MH, van Schalkwyk J, Van Eyk N. No. 233Antibiotic therapy in preterm premature rupture of the membranes. J Obstet Gynaecol Can 2017;39:e207-12.

8. The Royal Australian and New Zealand College of Obstetricians and Gynaecologists. Prophylactic antibiotics in obstetrics and gynaecology. Available from: https://www. ranzcog.edu.au/RANZCOG_SITE/media/RANZCOGMEDIA/Women\%27s\%20Health/Statement\%20and\%20 guidelines/Clinical\%20-\%20General/Prophylacticantibiotics-in-obstetrics-and-gynaecology-(C-Gen-17)Review-July-2016.pdf?ext=.pdf. Accessed 2 May 2019.

9. Wolf MF, Miron D, Peleg D, et al. Reconsidering the current preterm premature rupture of membranes antibiotic prophylactic protocol. Am J Perinatol 2015;32:1247-50.

10. Jeong H, Han SJ, Yoo HN, et al. Comparison of changes in etiologic microorganisms causing early onset neonatal sepsis between preterm labor and preterm premature rupture of membranes. J Matern Fetal Neonatal Med 2015;28:1923-8.

11. von Elm E, Altman DG, Egger M, et al. The Strengthening the Reporting of Observational Studies in Epidemiology (STROBE) statement: guidelines for reporting observational studies. Epidemiology 2007;18:800-4. 
12. Kim YA, Lee K, Chung JE. Risk factors and molecular features of sequence type (ST) 131 extended-spectrum$\beta$-lactamase-producing Escherichia coli in communityonset female genital tract infections. BMC Infect Dis 2018;18:250.

13. Cullen IM, Manecksha RP, McCullagh E, et al. The changing pattern of antimicrobial resistance within 42,033 Escherichia coli isolates from nosocomial, community and urology patient-specific urinary tract infections, Dublin, 1999-2009. BJU Int 2012;109:1198-206.

14. Tuem KB, Gebre AK, Atey TM, Bitew H, Yimer EM, Berhe DF. Drug resistance patterns of Escherichia coli in Ethiopia: a meta-analysis. Biomed Res Int 2018;2018:4536905.

15. Andremont A, Gerbaud G, Courvalin P. Plasmid-mediated high-level resistance to erythromycin in Escherichia coli. Antimicrob Agents Chemother 1986;29:515-8.

16. August Fuhr N, Becker C, van Baalen A, Bauer K, Hopp $\mathrm{H}$. Antibiotic therapy for preterm premature rupture of membranes-results of a multicenter study. J Perinat Med 2006;34:203-6.

17. Johnston MM, Sanchez-Ramos L, Vaughn AJ, Todd MW, Benrubi GI. Antibiotic therapy in preterm premature rupture of membranes: a randomized, prospective, doubleblind trial. Am J Obstet Gynecol 1990;163:743-7.

18. Lockwood CJ, Costigan K, Ghidini A, et al. Doubleblind; placebo-controlled trial of piperacillin prophylaxis in preterm membrane rupture. Am J Obstet Gynecol 1993;169:970-6.

19. Gupta K. Addressing antibiotic resistance. Am J Med 2002;113 Suppl 1A:29S-34S.

20. Lee J, Romero R, Kim SM, Chaemsaithong P, Yoon BH. A new antibiotic regimen treats and prevents intra-amniotic inflammation/infection in patients with preterm PROM. J Matern Fetal Neonatal Med 2016;29:2727-37.

21. Muller A, Lopez-Lozano JM, Bertrand X, Talon D. Relationship between ceftriaxone use and resistance to third-generation cephalosporins among clinical strains of Enterobacter cloacae. J Antimicrob Chemother 2004:54:173-7.

22. Fung-Tomc JC, Gradelski E, Huczko E, Dougherty TJ, Kessler RE, Bonner DP. Differences in the resistant variants of Enterobacter cloacae selected by extendedspectrum cephalosporins. Antimicrob Agents Chemother 1996;40:1289-93. 